\title{
Mining Sector and Its Impact on Odisha Economy: Proper Utilization of Limited Resources using Forecasting Techniques
}

\author{
Gitanjali Panda* \\ Fakir Mohan University, Balasore, Odisha, India \\ *Corresponding author: gitanjalipanda16@gmail.com
}

Received August 22, 2014; Revised August 25, 2014; Accepted October 24, 2014

\begin{abstract}
In this paper an attempt has been made to show the economic significance of mining sector in the context of Orissa Economy in terms of value of total extractions, total employment generation and contribution of mining sector to State Gross Domestic Product and total revenue generation. Despite being the highest mineral rich state of the country, the state is designated as one of the poorest states because benefits of mining have gone to few hands caused by large scale corruption. The paper has explored how corruption starting from allotment of lease till the valuation of minerals and fixation of royalties has deprived the state exchequer from its dues, resulting in greater inequalities between the rich and the poor in the state.
\end{abstract}

Keywords: mining, limited resources, corruption, economy, forecasting analysis

Cite This Article: Gitanjali Panda, "Mining Sector and Its Impact on Odisha Economy: Proper Utilization of Limited Resources using Forecasting Techniques.” Journal of Business and Management Sciences, vol. 2, no. 3A (2014): 41-45. doi: 10.12691/jbms-2-3A-6.

\section{Introduction}

Minerals have been major natural resource exploited by humans from times immemorial. The rapid industrialization and infrastructure development has resulted in increased demand and large scale exploitation of the mineral resources. In this regard, National Mineral Policy, 2008, recognizing minerals as vital raw material for infrastructure, capital goods and basic industries, emphasizes on the need for adoption and use of scientific methods for maximizing mineral exploration and prospecting for mining, beneficiation and economic utilization. It has also identified key priority areas such as enhancing resource and reserve base through exploration and internal acquisition, reducing permit delays, putting in place core enablers infrastructure, human capital, and technology), ensuring sustainable mining and sustainable development around mining; emphasis has been laid on creating information, education and communication strategy to achieve the goal.

Odisha is one of the mineral rich states of the country having a special distinction in the country's overall mining sector. It has attracted large scale private investments to mining sector in last two decades. Large scale illegal mining in Orissa has caused damages for the economy as a whole, particularly the life of tribals who are the inhabitants of mining area. Keeping this in view, the paper examines the significance of mining for the growth of the economy and to discuss the sources of corruption in this activities and its socio-economic and environmental impact around the mining area.

\section{Economic Significance of Mining in Orissa Economy}

The total value of minerals produced in Odisha is highest in the country. Its share in the all India total is $11.89 \%$ while it is $7.13 \%$ for Rajasthan and $6.74 \%$ for Gujarat. The contribution of other states like Madhya Pradesh, Assam, Andhra Pradesh, and Karnataka is 4.99\%, 4.79\%, 4.63\% and 3.78\% respectively (Indian Bureau of Mines). As per the Odisha Economic Survey 2011-12, state ranks highest in India in recent years in term of value of output of minerals and its share has been increasing. The mining sector contributes about 7.3\% of the real GSDP of Odisha. In terms of value of mineral production, mineral production at national level had the share of $25.64 \%$. It is indicated that though Orissa is having the highest resource base, the contribution of minerals to SGDP is not satisfactory. Being a favored investment destination of global investors, this sector seems poised for rapid growth. But the irony of the situation is that despite being the most mineral rich state, it is one of the poorest state of the country, few people of the state are becoming rich capitalist at the cost of the state natural resources.

\section{Significance of Mining in terms of Employment Generation}

The indicator of the economic significance of sector is often reflected through its employment generating 
capacity as India as well as Odisha has been experiencing high incidence of unemployment since independence.

Table 1. Annual Growth of Employment in Different Year

\begin{tabular}{|c|c|c|}
\hline Year & No. of Employment & Annual Growth of Employment \\
\hline $2004-2005$ & 49837 & - \\
\hline $2005-06$ & 55764 & 11.89 \\
\hline $2006-07$ & 47376 & -15.042 \\
\hline $2007-08$ & 49176 & 3.801 \\
\hline $2008-09$ & 44167 & -10.19 \\
\hline $2009-10$ & 43705 & -1.05 \\
\hline $2010-11$ & 51877 & 18.69 \\
\hline
\end{tabular}

Source-Director of Mines, Orissa.

Mining and Quarrying provides employment to different sections including tribal groups. The above Table 1 shows the number of workers directly engaged in various mining activities from 2004-2005.There has been negative growth in some of the years because this sector has been increasingly employing labour-saving and capital-intensive production techniques and technology over the years. However, the employment has touched 51,877 by the end of 2010-2011 showing an increase of $18.7 \%$ over 2009 2010.From equity point of view the mining sector is not conducive for poverty alleviation through employment generation.

\section{Revenue Collections, Value of Production from Mining Activities in Odisha}

The Table 2 indicates that the importance of mining activities in Orissa during 2001-2011 in terms of revenue collections, percentage contribution of mining to Gross State Domestic Product and percentage of revenue from mining to total revenue and growth rate total production of minerals and value of production which have shown a upward trend.

Table 2. Percentage Growth of Contribution and Revenue of Mining in Different Years

\begin{tabular}{|c|c|c|c|c|c|c|c|c|}
\hline Year & $\begin{array}{c}\text { Total } \\
\text { collection } \\
\text { of mining } \\
\text { revenue }\end{array}$ & $\begin{array}{l}\text { Contribution } \\
\text { of mining to } \\
\text { GSDP }\end{array}$ & State GSDP & $\begin{array}{l}\text { \% contribution } \\
\text { of mining to } \\
\text { GSDP }\end{array}$ & $\begin{array}{l}\text { Production( } \\
\text { in lakh } \\
\text { tons) }\end{array}$ & $\begin{array}{c}\text { Value of } \\
\text { production( rs } \\
\text { in Crorers) }\end{array}$ & $\begin{array}{c}\text { Total } \\
\text { Revenue } \\
\text { receipts ( Rs } \\
\text { in Crorers) } \\
\end{array}$ & $\begin{array}{c}\% \text { of } \\
\text { Revenue in } \\
\text { Mining to } \\
\text { total revenue }\end{array}$ \\
\hline 2001-02 & 378.36 & 2503.44 & 46755.74 & 5.35 & 749.81 & 2910.47 & 7047.98 & 5.368389241 \\
\hline 2002-03 & 443.54 & 3012.73 & 49712.61 & 6.06 & 873.62 & 3694.17 & 8438.76 & 5.255928596 \\
\hline 2003-04 & 550.76 & 4300.5 & 61007.93 & 7.05 & 1080 & 3877.75 & 9440.24 & 5.834222435 \\
\hline 2004-05 & 670.51 & 5861.86 & 77729.43 & 7.54 & 1270.48 & 6130.93 & 11850.19 & 5.658221514 \\
\hline 2005-06 & 805.00 & 7126.78 & 85096.49 & 8.37 & 1396.78 & 6604.41 & 14084.71 & 5.715426871 \\
\hline 2006-07 & 936.56 & 8662.77 & 101839.47 & 8.51 & 1614.45 & 7629.63 & 18032.62 & 5.193671801 \\
\hline 2007-08 & 1126.09 & 12247.54 & 129274.45 & 9.47 & 1784.23 & 10627.05 & 21967.19 & 5.126252379 \\
\hline 2008-09 & 1380.59 & 15937.37 & 148490.71 & 10.73 & 1889.55 & 15122.9 & 24610.01 & 5.609883133 \\
\hline 2009-10 & 2020.72 & 15395.02 & 163726.56 & 9.40 & 1988.4 & 15317.1 & 26430.21 & 7.645493169 \\
\hline 2010-11 & 3330.47 & 19154.18 & 195027.68 & 9.82 & 2078 & 28287.13 & 33276.15 & 10.0085698 \\
\hline 2011-12 & 4586.65 & 24431.35 & 226236.14 & 10.80 & 3995.911 & 42607.96 & 58267.696 & 16.08 \\
\hline $\begin{array}{c}\text { Growth rate(\%) } \\
\text { CAGR }\end{array}$ & 28.16 & 25.69 & 17.8 & & 12,13 & 26.68 & 19.11 & \\
\hline
\end{tabular}

Source: Orissa Mining Corporation.

The size of mining sector has grown at a rate of $26.69 \%$ more than that of State GSDP, growing at a rate of $17.8 \%$. Contribution of mining sector to GSDP has increased from $5.35 \%$ to $10.80 \%$ in last 11 y ears. Revenue from mining sector has grown at a greater rate than total revenue. The reports of Shah commission tabled in the Parliament have a negative impact on mining extractions in Odisha. In Table 3 the value of $R^{2}$ is 0.899 , it assumes that the dependent variable is strongly associated with the all the independent variables. Table 4 indicates that the model $y=a+b t$ or percentage contribution of mining $=a+b($ year $)$ is statistically significant with $95 \%$ level of significance since the $\mathrm{P}$ value is 0.000 which is less than 0.05 . So we may reject the null hypothesis means the model is significant. Table 5 indicates that the percentage contribution of mining is dependent with the time so the equation is $y=5.364+0.517$ (year) and since $\mathrm{P}$ value of the coefficient of year i.e. 0.00 is less than 0.05 so, year is significant to fit the model for evaluating the percentage contribution of mining. In Table 6 the value of $\mathrm{R}^{2}$ is 0.489 , it assumes that the dependent variable is moderately associated with the all the independent variables. Table 7 indicates that the model $y=a+b t$ or percentage revenue of mining $=a+b$ (year $)$ is statistically significant with $95 \%$ level of significance since the $\mathrm{P}$ value is 0.017 which is less than 0.05 . So we may reject the null hypothesis means the model is significant. Table 8 indicates that the percentage revenue of mining is dependent with the time so the equation is $y=2.828+0.703$ (year) and since $\mathrm{P}$ value of the coefficient of year i.e. 0.017 is less than 0.05 so, year is significant to fit the model for evaluating the percentage contribution of mining. Figure 1 and Figure 2 represent the histogram of time with respect to percentage contribution and percentage revenue of mining respectively.

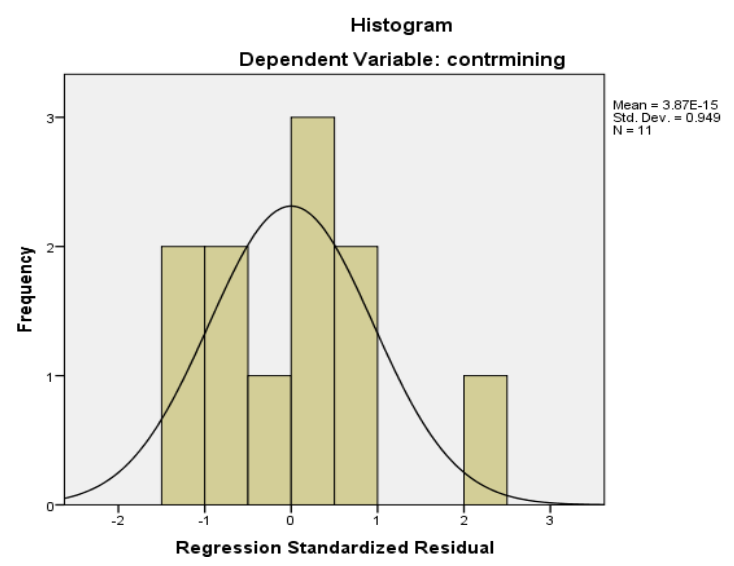

Figure 1. Histogram of Year and Percentage Contribution of Mining 
Table 3. Model Summary ${ }^{\mathrm{b}}$ of Percentage Contribution of Mining

\begin{tabular}{|c|c|c|c|c|c|}
\hline Model & $\mathrm{R}$ & $\begin{array}{c}\mathrm{R} \\
\text { Square }\end{array}$ & $\begin{array}{c}\text { Adjusted R } \\
\text { Square }\end{array}$ & $\begin{array}{c}\text { Std. Error } \\
\text { of the } \\
\text { Estimate }\end{array}$ & $\begin{array}{c}\text { Durbin- } \\
\text { Watson }\end{array}$ \\
\hline 1 & $.948^{\mathrm{a}}$ & .899 & .887 & .60633 & 1.477 \\
\hline
\end{tabular}

a. Predictors: (Constant), year

b. Dependent Variable: contrmining

Table 4. ANOVA ${ }^{\mathrm{a}}$ of Percentage Contribution of Mining

\begin{tabular}{|cc|c|c|c|c|c|}
\hline \multicolumn{2}{|c|}{ Model } & $\begin{array}{c}\text { Sum of } \\
\text { Squares }\end{array}$ & df & $\begin{array}{c}\text { Mean } \\
\text { Square }\end{array}$ & F & Sig. \\
\hline \multirow{2}{*}{1} & Regression & 29.350 & 1 & 29.350 & 79.834 & $.000^{\mathrm{b}}$ \\
& Residual & 3.309 & 9 & .368 & & \\
& Total & 32.659 & 10 & & & \\
\hline
\end{tabular}

a. Dependent Variable: contrmining

b. Predictors: (Constant), year

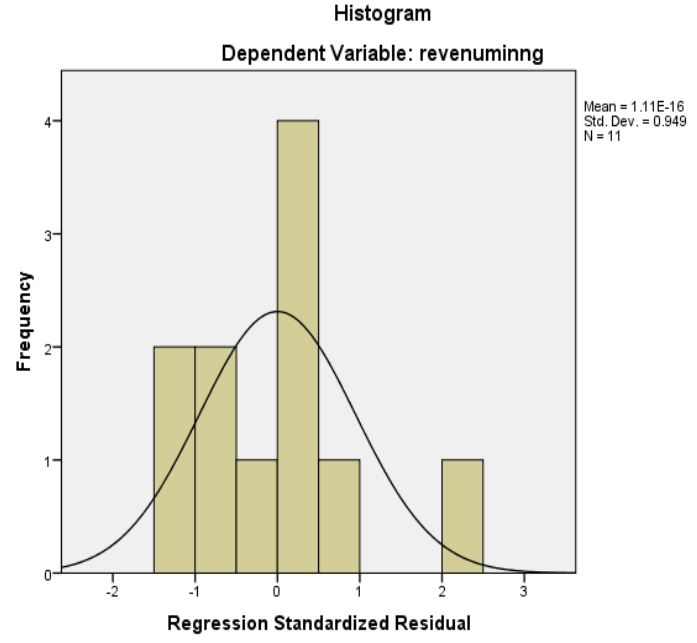

Figure 2. Histogram of Year and Percentage Revenue of Mining

Table 5. Coefficients ${ }^{\mathrm{a}}$ of Percentage Contribution of Mining

\begin{tabular}{|c|c|c|c|c|c|c|c|}
\hline \multirow{2}{*}{ Model } & \multicolumn{2}{|c|}{ Unstandardized Coefficients } & \multirow{2}{*}{$\begin{array}{c}\text { Standardized Coefficients } \\
\text { Beta } \\
\end{array}$} & \multirow{2}{*}{$\mathrm{T}$} & \multirow{2}{*}{ Sig. } & \multicolumn{2}{|c|}{ 95.0\% Confidence Interval for B } \\
\hline & $\mathrm{B}$ & Std. Error & & & & Lower Bound & Upper Bound \\
\hline $\begin{array}{cc} & \text { (Constant) } \\
\text { Year }\end{array}$ & $\begin{array}{c}5.364 \\
.517\end{array}$ & $\begin{array}{l}.392 \\
.058\end{array}$ & .948 & $\begin{array}{c}13.681 \\
8.935\end{array}$ & $\begin{array}{l}.000 \\
.000\end{array}$ & $\begin{array}{c}4.477 \\
386\end{array}$ & $\begin{array}{c}6.251 \\
647\end{array}$ \\
\hline
\end{tabular}

a. Dependent Variable: contrmining.

Table 6. Model Summary ${ }^{\mathrm{b}}$ of Percentage Contribution of Mining

\begin{tabular}{|c|c|c|c|c|c|}
\hline Model & $\mathrm{R}$ & $\begin{array}{c}\mathrm{R} \\
\text { Square }\end{array}$ & $\begin{array}{c}\text { Adjusted R } \\
\text { Square }\end{array}$ & $\begin{array}{c}\text { Std. Error of } \\
\text { the Estimate }\end{array}$ & $\begin{array}{c}\text { Durbin- } \\
\text { Watson }\end{array}$ \\
\hline 1 & $.699^{\mathrm{a}}$ & .489 & .432 & 2.51148 & .658 \\
\hline
\end{tabular}

a. Predictors: (Constant), year

b. Dependent Variable: revenuminng
Table 7. ANOVA ${ }^{\mathrm{a}}$ of Percentage Contribution of Mining

\begin{tabular}{|cc|c|c|c|c|c|}
\hline & Model & Sum of Squares & Df & Mean Square & F & Sig. \\
\hline \multirow{4}{*}{1} & Regression & 54.344 & 1 & 54.344 & 8.616 & $.017^{\mathrm{b}}$ \\
& Residual & 56.768 & 9 & 6.308 & & \\
& Total & 111.112 & 10 & & & \\
\hline
\end{tabular}

a. Dependent Variable: revenuminng

b. Predictors: (Constant), year

Table 8. Coefficients ${ }^{\mathrm{a}}$ of Percentage Contribution of Mining

\begin{tabular}{|c|c|c|c|c|c|c|c|c|}
\hline \multirow{2}{*}{\multicolumn{2}{|c|}{ Model }} & \multicolumn{2}{|c|}{ Unstandardized Coefficients } & \multirow{2}{*}{$\begin{array}{c}\text { Standardized Coefficients } \\
\text { Beta } \\
\end{array}$} & \multirow{2}{*}{$\mathrm{t}$} & \multirow{2}{*}{ Sig. } & \multicolumn{2}{|c|}{ 95.0\% Confidence Interval for B } \\
\hline & & B & Std. Error & & & & Lower Bound & Upper Bound \\
\hline \multirow{2}{*}{1} & (Constant) & 2.828 & 1.624 & & 1.741 & .116 & -.846 & 6.502 \\
\hline & Year & .703 & .239 & .699 & 2.935 & .017 & .161 & 1.245 \\
\hline
\end{tabular}

a. Dependent Variable: revenuminng

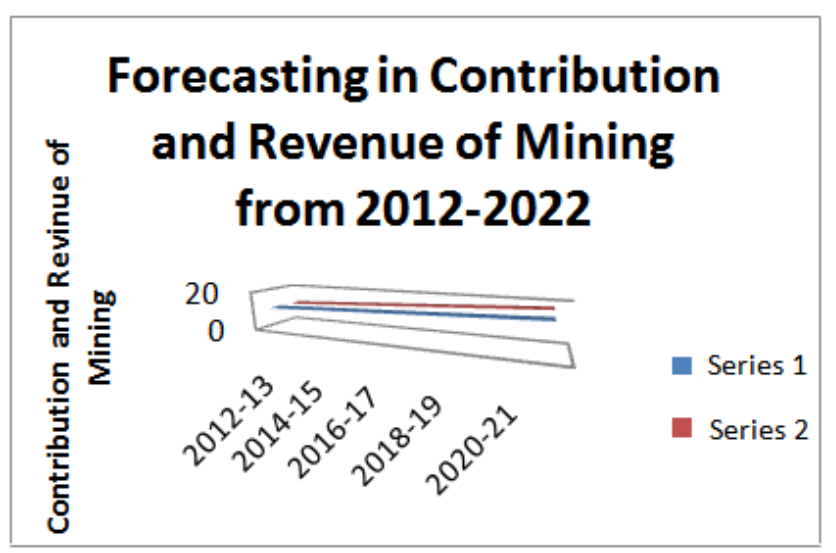

Figure 3. Forecasting in Percentage in Contribution and Revenue of Mining from 2012-2022

\section{Impact of Mining Sector Extractions on GSDP}

Figure 3 represents forecasting in percentage in contribution and revenue of mining from 2012-2022.
Regression analysis has been drawn on log value of GSDP due to change in the production of Minerals which is found to be 1.38 and significant at $0.05 \%$.As the calculated t-value is more than tabulated vale, we can infer that the economic growth of the state definitely depends on the growth of the mining sector. The ores from Odisha are feeder to Steel, Power, Aluminum, Cement and many other major industries. The minerals from Odisha are also exported to various countries. In the last decade, China has been the major buyer of minerals (Iron ore) from Odisha.

Elasticity of GSDP to production of Minerals $\operatorname{Ln}(G S D P)=0.62+1.386 \ln$ (Production from Mining Sector) $\mathrm{se}=0.33 \quad 0.10, \quad \mathrm{t}$ value $==1.8813 .33$, $\mathrm{p}$-value $=0.09$ $0.0095, \mathrm{R}^{2}=0.96$

Elasticity of total revenue to change of tax revenue $\mathrm{Ln}$ (Total revenue receipts) $=1.947+0.755 \ln$ (Mining revenues) Standard Error $\quad=0.2040 .068 \mathrm{t}$-valu $=9.5211 .01$

Elasticity of total revenue and revenue from mining sector is only 0.75 .which is significant at 5 percent level of significance. Definitely, the growth of the Odisha Economy depend on the growth of mining sector, but the revenue generation from this sector has not been satisfactory. That means the state has failed to garner the 
benefits from its natural resources in terms of revenue collection.

\section{Reasons for Low Revenue Generation}

\subsection{Irregularities and Corruption in Mining Sector}

One of the major causes is the existence of irregularities in executing the rules and regulations formulated by the state government and central Government. Any business unit that is involved in mining activities has to comply with the rules \& regulations formulated by the state Government as well as Central Government. Before giving permission for mining activities, the government authorities need to cross check number of statutory clearances from different organizations like approved Mining Plan, clearance in respect of Forest \& Environment, State Pollution Control Board etc.

Irregularities are found concerning allotment of mining leases, determination of royalties and transportation of minerals. Due to complexities involved in the mining activities, it is very difficult to control and monitor the mineral extraction, transportation and royalty collection. There has to be proper synchronization between the quantities of mineral excavated, transported and receipt.

The Mines and Minerals (Development and Regulation Act, 1957 (MMDR) and the Mines Act, 1952, together with the rules and regulations framed under them, constitute the basic laws governing the mining sector. The relevant rules in force under the MMDR Act, are the Mineral Concession Rules, 1960, and the Mineral Conservation and Development Rules, 1988.

With regard to the present provision, there was a scope for collusion among officials, politicians and lice cense holder in promoting illegal mining. The guidelines under the Central and the state enactments, call for a sketch of the mining area when a mining lease is applied for. It was found by Shaha Commission that sometimes the actual mining areas are not related to the sketch given with the applications without officials crosschecking them. Further mining applicants falsely claim a prohibited forest area as a revenue area. Finally the actual area of the mine is much bigger than the claimed area. The Indian Bureau of Mines rules which control the type of mining, allow a maximum mining depth six metres to prevent environmental degradation. But miners have flouted this rule to overextract iron-ore. For example, if they are allowed to take 100 metric tons, mines take 1,000 metric tonnes. Officials at road check posts reportedly collude in a massive undercounting of lorries and trucks transporting the iron-ore. In Orissa the allotment was done on first cum first served basis which has given a scope for the nexus between politicians, people and officials. The scope for nepotism was high.

\subsection{Underpayment of Royalties to State}

There is a huge difference in the market price of the ore and the royalty specified by the government as well as faulty measurement mechanisms of amount of ore extracted. The pea-nut royalty paid by lease-holder swelled his own pocket and the pockets of the officials and the politicians. In Sec 9 of the MMDR Act has provision with regard to royalty payment by the holders of mining leases. Schedule 2 of the Act provides for the rate of royalty payment in respect of various minerals including iron ore. The provision with regard to iron ore is $10 \%$ of sale price on ad valorem basis. The Indian Bureau of Mines publishes 'Monthly Statistics of Mineral Production' which contains state-wise total value of each mineral produced during a month in a State. The Statewise average value for different individual minerals as published by Indian Bureau of mines in the 'Monthly Statistics of Mineral Production' shall be the bench mark for computation of royalty by the concerned State Government in respect of any mineral produced any time during a month in any mine in that State. For the purpose of computation of royalty the State Government shall add twenty per cent to this bench mark value. This value shall be reckoned to be the sale price for the purpose of computation of royalty. Also the value of the minerals published in the latest published issue of the 'Monthly Production' will be deemed to be applicable for the mineral mined in the previous month, irrespective of when the royalty actually accrues. If for a particular mineral, the information for a State is not published in a particular issue, the last information available for that mineral in the State in a previous issue shall be referred, failing which the latest published information for the mineral for all India shall be referred."

As per the Hoda Committee report, the procedure adopted by IBM for fixing the sale value of iron ore is found to contain numerous discrepancies such as procedural failure in calculation of sale price, high variation in prices in respect of particular grades of iron and ore and under-reporting and incorrect reporting of prices.

One of the major cause of under collection is absence of a credible system of checks and balances in the process of extraction, transport, trade and at end user points, checking transportation of illicit iron. The weaknesses of the present system are as follows: 1)Permits issued at the public office shows discrepancy between the actual weight of iron and ore carried in the truck and the amount of iron and ore mentioned in the trip sheet issued to the lessee.

Since introduction of Ad valorem rate of royalty on the minerals, IBM has been publishing the sale value/price of minerals for different states. The methodology being used is flawed and the manner in which it is implemented is detrimental to the State's interest as the sale value does not accurately reflect the market price of the minerals/ore. As a result, the State is losing huge revenue in terms of mining royalty.

\subsection{Under-invoicing of Exports}

The Indian government (steel ministry and law ministry) is considering a ban on exports of iron ore and limit mining only to captive iron and steel production units. This has been opposed by the mining ministry citing massive loss of employment. During discussions with officers, among others, it was also revealed that there are cases of under-invoicing in iron ore exports sales.

\section{Impact of Mining on Tribals' Livelihood and Environment}


Mining in Orissa has generated controversy, which spans encroachment of forest areas, underpayment of government royalties, and conflict with tribals regarding land-rights. The spill-over of the effects of illegal mining into problems such as Naxalism and the distortion of Indian democracy by mixed political and mining interests, has gained international attention. Bauxite and coal mining by Vedanta Resources in tribal areas of Orissa have led to conflicts in land rights Coal mining has run into trouble as well in Angul district over land issues. The livelihood of lakhs of tribals was affected due to closure of mines in both Sundergarh and Keonjhar districts.

There have been severe ecological changes due to illegal mining. Certain species of animals and medicinal plants disappear due to large-scale mining. It is reported that the area surrounding the mining area is denuded of greenery and agricultural activity gets affected in mineralbased districts.

\section{Environmental Damage}

According to the Lokayukta Report there have been severe ecological changes due to illegal mining. Certain species of animals, like the sloth bear, that in the Bellary region have disappeared. Medicinal plants from the area do not grow anymore. The entire system of rain has changed in the district of Bellary. It is reported that the entire area surrounding the mining area is denuded of greenery and has no agricultural activity Related road damage, accidents and loss of lives. Lack of effective regulation in the mining and transport of iron has adversely impacted road safety.

\section{Conclusion}

The issues relating to much discussed illegal mining activities have brought no good for the Odisha Economy. The windfall gains resulting from mining activities in Odisha have caused serious systemic distortions. There has been allegations of large-scale corruption which has resulted in lesser contribution of revenue to the state exchequer. The revenue which could have been used for social sector development have gone to the hands of a few people of the society, causing inequality in the society. There should be a credible system of check and balances in the process of extraction, transport, trade and end-user point. An effective control and regulation over mining activities can be enabled through use of Information and Communication Technology (IC\&T) tools. The responsibility of the infrastructural development of the mining area should be vested on the benefitted private sector. It is known fact that mineral resources are finite. Keeping in the requirement of the industries, there should be proper balance between exploitation and augmentation.

\section{References}

[1] Asher, M. (2006). Steel not enough, Economic and Political Weekly, February 18.

[2] Pradhan, J.P. (2007). Tata Steel's Romance with Orissa, Mineralbased Underdevelopment and Federal Politics in India, Institute for Studies in Industrial Development. New Delhi, February.

[3] Sahu, G. (2008). Mining in Niyamgiri Hills and Tribal Rights, EPW, April 12.

[4] Economic Survey, (2011-2012). Government of Orissa, Planning and Coordination Department.

[5] Mining Resources of Orissa Document, (2012). Mining Corporation of Odisha. 